\title{
DANGERS THAT LURK IN THE RECALL OF THE JUDICIARY
}

\author{
By James A. Metcalf, \\ Editor, The Dawson County Review, Glendive, Mont.
}

The adoption of a constitutional amendment making the "Recall" applicable to the judiciary would mean the substitution of the popular will, with its unavoidable temporary uncertainties, for the judicial determination of the every-day causes which now engage the attention of the courts.

In spite of their praiseworthy faith in the rectitude of the ultimate conclusion of the people; and no matter how logical or plausible their arguments in behalf of this revolutionary device for reversing the expressed will of the electorate in regard to officials in legislative or administrative position, the most ardent advocates of the recall must admit that, when used as a weapon for intimidating the judiciary, it involves the gravest possible dangers to the stability of constitutional government.

From the very nature of the functions they perform, the judges must be removed from prejudicial influences of whatsoever character. Granted that the courts have been influenced by the money power, and that a different condition must prevail in order to guarantee the security of popular rights, yet what good can be accomplished by swinging to the opposite extreme? Two wrongs do not make a right. And there must be a happy medium wherein the rights of all shall be fully respected and protected. Our sacred duty as American citizens, and every consideration of personal and general welfare impel us to seek that middle ground of safety, rather than unnecessarily fly to some radical extreme.

If we can devise some general reform, whereby we shall limit the power of the courts in the determination of the question of constitutionality, we shall have abolished the real evil of "judgemade law," with its present power of substitution for the will of the people, without in the least impairing the ability or courage of the courts in the daily administration of justice between man and man. Let us add thereto some limitation to be placed upon technical 
jurisprudence and its power to obscure the real issues or prevent the attainment of justice and equity, and we will have corrected our worst evils without disturbing the general course and conduct of civil affairs.

\section{Instability of Government-Then Anarchy}

Out of the adoption and enforcement of the recall of the judiciary promises to issue a threatening array of iconoclastic agencies that are of serious portent to free government. First must come a period of uncertainty; then of wavering; then of fear; then of time-serving; then of debauchery induced by a system under which the dishonest jurist might well say: "Whatever step I take, I am apt to be recalled. Why not profit by the situation while it lasts, and sell myself for a good price?" Given a few years of the recalland then anarchy!

For example, imagine the instability of government that would have prevailed under the recall system during the past ten years, during which period our courts have been trying to reach a proper interpretation and enforcement of the laws governing industrial monopolies. What judge would have dared take a strong stand, one way or the other, without facing the certainty of being recalled to private life? You may at once advert to the fact that these years of effort and great expenditure of time and money in the courts have not brought us to any definite conclusion of the corporation question. But, on the other hand, the frequent disruption of the courts through recalling of judges would have accomplished no good, and the conclusions eventually forced by fear from a spineless judiciary might have been far from right or just or safe. They could hardly be called "conclusions of law" under such circumstances. I do not believe these are either fanciful or far-fetched pictures of scenes that might be enacted under a recall system.

\section{"The Complexity of the Law" is Unavoidable}

It is eminently right and proper that popular discussion and expression of preference should have its effect upon the courts; and it does to a very great extent. But these great problems, with their infinity of detail and ramifications of principles, are not proper subjects for superficial or popular determination. The public mind, awakened to a full moral consciousness, grasps the great principle of things 
in its superficial entirety, but is lost in the intricacy of its legal complexity. The people know what they want, and should have it; but the consideration of orderly procedure is of paramount importance. Some will doubtless say, at this point: "Abolish the complexity of the law entirely. Bring it within the comprehension of the laity. The intricacy of the law is the very thing that gives it the character of a maze, within which the artful attorney wanders at will to the subserving of special interests, while the rights of the people get wholly and hopelessly lost."

There seems to be much justice in this complaint. If directed to a right remedy, its insistence cannot be denied. But its misdirected gaze loses sight of the fact that the body of the law is not an arbitrary arrangement of set rules and forms, which can be turned or twisted at will, or wiped out of existence and replaced by others in a moment of time. The judicial system is a part of the bone and sinew of the nation. The lines of the law are inextricably interwoven with the very network of civilization. The law has grown as the world has grown. It has developed just as fast as human intelligence has expanded. It is wholly inseparable from the web and woof of civil government. When the law weakens, liberty totters to its fall.

The very complexity of the law is of inherent necessity. Its every principle is a mile-post on the arduous ascent out of the valley of ignorance and superstition to the sunlit mountain-top of enfranchised intellect. Its every phase reflects the light of some victorious battle fought in the name of human happiness. Its every development marks a new step in the progress of mankind; and yet the old tenets must be retained, the precedents must be preserved, because human nature in the ultimate does not change with the passing of time, and every just decision of the courts must prove its consistency and authenticity by adherence to the principles that have been developed and perfected through countless racial struggles, out of which man has grown upward toward the perfect stature of divinity.

Certain well-defined principles of jurisprudence, when in action, are not necessarily then and there traced to their origin, nor obliged to travel wearily backward through ages of history in order to fetch forward their credentials. They have been such frequent visitors to the courts as to become well known. Yet each must be ready 
at all times to stand the test of conformity with practice and precedent, and to survive a rigid application of all the rules of the common and statutory law.

How utterly vain to hope or expect that these infinite details, which provide a task of impossible comprehension even in a lifetime of exclusive study and research, should be brought immediately within the popular understanding. And if the people cannot comprehend and follow the full workings of the law, they are certainly not qualified to criticise the individual decisions of the courts, nor to declare the rightful deposition of the just or unjust judge who offends, as the case may be.

However, we must make an exception here, and must distinguish between the existence or survival of a law and its application to some particular state of facts or circumstances. The right to say what the law shall be resides solely in the people; the function of its application to each separate case belongs to the courts. The people, exercising the power of popular government, make the yardstick of the law; the courts will do the measuring, but must not change the unit of measurement. The distinction seems to be clear, unequivocal, thoroughly just and founded upon a proper conception of representative government.

\section{Justice Must be "Judicially" Administered}

Though we have superimposed many innovations upon jurisprudential practices in these later days, we must still yield to the immortal Blackstone the distinction of having evolved the most comprehensive and desirable definition of a court, namely, "a place where justice is judicially administered."

It may be taken for granted that American citizenship, as a whole, desires the courts of the land to furnish an exemplar of Blackstone's definition. Failing at times to realize such a desire, and recognizing the existence of evils which should unquestionably be eradicated in some manner, we are prone to a radical reformation that seems necessary only because we have blamed the courts too severely for the existence and spread of a general political or civil malady. Upon them we have undoubtedly heaped a greater responsibility than they deserve or merit for the failure of the laws to produce the proper effect in the preservation of popular rights.

Much, if not all, of the sanction of the law depends upon an 
enlightened public opinion. Without a militant supporting sentiment back of it, no law can be successfully enforced. The courts can be no better, no more conscientious, no more patriotic than the civil environment within which they exist. And it is subversive of political principle, detrimental to right thinking and inimical to free government for us to ascribe undue discredit to the courts. Nothing in history nor in present conditions warrants the contention that any considerable portion of the judiciary is venal or corrupt. The American bench has been occupied by a succession of highminded, noble-spirited, warm-hearted jurists-men who have given a faithful interpretation to the laws and have unfalteringly preserved and protected the constitution as the divinely-inspired magna charta of American liberty.

\section{Not Only the "Special Interests" are Concerned}

It is true that corporation-controlled courts have been a disgrace to the United States in notable instances. But we must also remember that the "special interests" have reached out and controlled not only the judicial, but also the legislative and administrative branches of government.

Fully recognizing the evils that have fastened themselves upon our government, and being fully aroused to the necessity of doing something to purify politics and cleanse the courts-and that right speedily-our greatest danger to-day lies in the tendency to resort to too radical reforms. And of the proposed innovations of doubtful expediency, the recall of the judiciary stands forth as the most dangerous. We have other ways of making the courts amenable to just and patriotic considerations, and to wean them away from illicit alliances, than by suspending above them this sword of Damocles. The power of impeachment has not waned, and it still stands as a powerful weapon in the hands of an enlightened and conscientious commonwealth.

And we must not for a moment forget that the courts we complain of control not only the interpretation of the laws affecting the "special interests," but that they have always been and still are the final arbiters of our constitutional rights-the very last bulwark of our liberty. And for the sake of correcting one class of evils, which can undoubtedly be remedied in some other and safer manner, we cannot afford to imperil any established safeguard of 
our "life, liberty and the pursuit of happiness" by the substitution of a fickle popular will for the judicial administration of justice through independent, high-minded courts of law such as we now undoubtedly possess.

\section{The Judicial Referendum}

In view of very recent political discussions, there should be added hereto a brief consideration of a proposed judicial reform which is sometimes referred to as "the recall of decisions," but which is more properly entitled "The Judicial Referendum."

There is no identity of operation or effect between the recall of judges and this proposed judicial referendum, and the two should not be confused in consideration. The one is demanded as an available weapon to be wielded by popular frenzy; the other is desired to be used as a well-considered, thoughtful means for insuring genuine popular government in finality.

The judicial referendum does not propose to disturb the judges in the exercise of their ordinary functions, nor in the determination of the multitudinous causes which make up the routine of the courts. It will not prejudice the decisions of the judges through fear or threat of the imposition of a personal penalty; in fact, its operation would have no direct relation to the personnel of the courts. In this respect it is entirely different from the recall, and it must not be judged from the same viewpoint. The dangers that pertain to the latter are entirely absent from the former.

\section{Question of "Constitutionality" Only}

The judicial referendum would have to do with the final determination of the constitutionality of the laws only. I can well understand that even this suggestion is a shock to the long-cherished doctrine of the infallibility and inviolate integrity of supreme court decisions. But let us note that the judicial referendum would simply proceed upon the undoubtedly correct theory that, in a genuinely popular government, the will of the people of right should be, and in our own government eventually must be, supreme in all things. It must be admitted in theory, even though the proposed practice be dubiously considered, that the people are entitled to clearly express their will and by some means make the same effective in every branch of the government. Therefore, if the courts shall 
determine, through resort to technicality or pure precedent, that a certain law is unconstitutional and shall thereupon suspend its operation, even though such law would seem to have been duly enacted by the people or their accredited representatives, it is contended that there shall still reside in the people, as of inherent right, the power to determine, by means of a judicial referendum invoked by petition in an orderly manner, whether such law shall finally stand in legal sufficiency and sanction.

\section{Not a "Recall of Decisions"}

It is not proper to name such a process "the recall of decisions," which phrase does not clearly establish its proper relation to the general scheme of government. It is of higher status than such a description would indicate. It is in reality the re-enactment of a law that has come into conflict with judicial conservatism. It constitutes a test of the certainty of the popular will through a required re-expression thereof and is in effect a broad application of the principle underlying the initiative and referendum. It has been described by some as a quick and easy means for effecting a constitutional amendment, but that again places it on a too low plane, for it occurs to me that legislation which had survived the adverse action of the supreme court and had been thereupon re-enacted into law by the direct vote of the people would possess even a greater sacredness and sanction than the constitution itself, whose title to veneration has hitherto rested largely upon its undisturbed existence as the generic, formative law of the land.

\section{No Disturbance of the Courts}

While the recall of judges would proceed with demoralization of the courts and would weaken the entire body of the law because of the resultant impotency of its interpreters and their constant fear of popular revenge, the operation of the judicial referendum would in no sense disturb or interrupt the ordinary course of jurisprudence, nor would it surround the judges with any greater uncertainty than now confronts them in the possibility of review and reversal by the court of final resort.

I do not apprehend that the judicial referendum system would abolish the supreme courts or lessen their usefulness. By its introduction we would simply erase from our present judicial system, 
the doctrine of the inviolability of decisions on constitutional questions, and would substitute the people as the court of final appeal, as the residual right of democracy. Full consideration would still be given supreme court decisions. In a majority of cases such decisions would undoubtedly stand without question, for they would be more carefully and conscientiously considered than is now sometimes the case. If any faction proposed to overturn a supreme court decision, the ultimatum of the court and its accompanying reasons would exert a strong moral effect for the preservation of peace and good order. The invocation of the judicial referendum would take time, and through it all, with platform, press and pulpit at work, no ill-considered or dangerous action would result.

\section{A Serious Question to Answer}

As we consider this whole problem we are faced with the serious question whether conditions generally do not warrant the people in the resumption of that power which they long ago delegated to their supreme courts, and which they are forced to believe has not always been rightly used. This is no threat to rob the courts of a rightful and inalienable possession. The people have given; the people can take away.

Finally, be it said: These suggestions do not profess to approach a measurable discussion of the judicial referendum, which is a great subject worthy of separate and careful treatment, but are simply designed to direct attention to a distinction which should be made between political doctrines prevailing at this time. 